УДк 617.555-007.43-02:616-089+616.756.22-089.844

DOI 10.11603/2414-4533.2020.2.10764

СМ. Г. ГОНЧАР ${ }^{1}$, А. Є. БОГУШ ${ }^{2}$, Л. Д. ПРИЙМАК ${ }^{2}$

Івано-Франківський національний медичний університет ${ }^{1}$

Центральна міська клінічна лікарня²

\title{
Хірургічне лікування пупкових гриж зі збереженням косметичного ефекту
}

Мета роботи: опрацювати методику операційного лікування пупкових гриж зі збереженням косметичного ефекту.

Матеріали і методи. У хірургічному відділенні центральної міської клінічної лікарні Івано-Франківська за 2016-2018 роки прооперовано 267 пацієнтів з пупковими грижами. 230 хворим виконано традиційні оперативні втручання за методикою Мейо, Сапежко або із застосуванням алотрансплантатів. 37 пацієнтам застосована оригінальна методика операції із збереженням пупка, яка була розроблена в клініці. Групи хворих за віком, статтю, видом та тривалістю патології були зіставними.

Результати дослідження та їх обговорення. Суть оригінальної методики полягає в наступному: розріз шкіри та підшкірної клітковини до апоневрозу проводили через пупок вертикально по відношенню до тулуба людини в вертикальному положенні. Виділяли грижовий мішок, розсікали, вміст його занурювали в черевну порожнину. Грижовий мішок перев’язували в основі і відсікали або зашивали очеревину обвивним швом. Ретельно очищали розширене пупкове кільце і нижчерозміщений апоневроз від підлеглих тканин і проводили пластику за Мейо або іншими способами. Після цього, при необхідності, висікали частину шкіри пупка, якщо вона його деформувала, і накладали оригінальний косметичний погружний шов, який захоплював дермальний шар шкіри і апоневроз. Вузол зав’язували під шкірою, яку зашивали косметичним швом. Інколи шов зміцнювали 1-2 вузловими швами. Запропонований метод хірургічного лікування пупкових гриж істотно не впливає на тривалість операції і навіть займає дещо менше часу - сумарний показник тривалості операції традиційним методом складав $(56,4 \pm 10,5)$ хв а при виконанні операції за оригінальною методикою - $(51,4 \pm 7,7)$ хв. За частотою ранових ускладнень групи оперованих хворих не відрізнялися. Це стосується і терміну перебування в стаціонарі - $(3,1 \pm 1,1)$ ліжко/дня.

Запропонована методика хірургічного лікування пупкових гриж невеликого розміру сприяє збереженню природної форми живота шляхом відновлення пупка і ліквідації його деформованої частини.

Ключові слова: пупкова грижа; розріз через пупок; погружний косметичний шов; косметичний ефект.

Постановка проблеми і аналіз останніх досліджень та публікацій. Перші письмові згадки про грижі живота з'явилися більше ніж три тисячі років тому і належать до часів папіруса Erbes в Єгипті. Відомості про грижі $є$ в роботах Гіппократа (IV cт. до н. е.), Цельса (I ст. до н. е.), Галена (II ст. до н. е.), Галідора (IV ст. до н. е.). Операційні засоби тих періодів були прості, примітивні і травматичні. Це відбувалося, тому що цирульники та інші особи, що займалися цією серйозною проблемою, підходили до іï̈ вирішення з механістичних позицій, i, як наслідок, залишили після себе слід в історії герніологої у вигляді ранових інфекцій, кастрацій, некрозів кишки та профузних кровотеч. Така ситуація зберігалась до кінця ХIX століття, перша половина якого характеризується появою ряду детальних анатомічних досліджень, початком нового підходу до вирішення вказаної проблеми.

Якщо перекинути місток з XIX століття в наш час, то можна сказати що хірургічні та анестезіологічні методи лікування пупкових гриж сягнули такого рівня, який дозволяє оперувати як дітей, так і людей похилого та старечого віку.

Сучасна статистика говорить про 20 мільйонів пацієнтів із грижами живота, яких оперують щороку, а це шоста частина від загального числа хворих, котрим показані хірургічні втручання.
Найпоширенішим способом хірургічного лікування пупкових гриж у дорослих $€$ методика Сапежко та Мейо, це не рахуючи лапароскопічних методик із застосуванням алотрансплантатів.

Однією $з$ важливих особливостей пупкових гриж $€$ значно більше механічне навантаження на зону пластики. За даними Х. С. Салахова (1991), навантаження на один шов при пупкових грижах складає $(3,1 \pm 0,8)$ кг, що значно більше, ніж при грижах інших локалізацій, у яких це навантаження на один шов складає в середньому $(2,6 \pm 0,7)$ кг.

Більш ніж вікове випробування традиційних методів довело їхню спроможність, тому хірурги сьогодні в більшості випадків надають перевагу традиційним методикам, а не лапароскопічним.

Поряд 3 цим, на сучасному рівні розвитку герніології постають питання косметичного плану, що стало причиною даної публікації.

Мета роботи: опрацювати методику операційного лікування пупкових гриж із збереженням косметичного ефекту.

Матеріали і методи. У хірургічному відділенні центральної міської клінічної лікарні Івано-Франківська, яка є базою кафедри хірургії стоматологічного факультету Івано-Франківського національного медичного університету, в період з 2016 по 
2018 рік включно було прооперовано 1456 хворих з грижами передньої черевної стінки. 3 них післяопераційні вентральні грижі були в 200 пацієнтів, пахові прямі та косі грижі - в 989 пацієнтів, пупкові - в 267 пацієнтів. Вік хворих коливався в межах від 18 до 86 років. Основна частина хворих припадає на працездатний вік (61 \%), жінки складають 64,3 \%, чоловіки - 35,7 \%. У 102 пацієнтів з пупковими грижами, які за класифікацією J. P. Chevre та A. M. Rats (1999) належать до групи W2-W5, виконували операційні втручання із застосуванням алотрансплантатів (сіток). Пацієнтам з пупковими грижами малого діаметра (W1) в основному виконували натяжні методи оперативного втручання (57 \%) в більшості випадків за методом Мейо.

Післяопераційні вентральні грижі ішли під грифом “спайкова хвороба очеревини”. В зв’язку з цим пацієнтам виконували насамперед ентероліз, а потім - пластичну операцію із застосуванням сітчастого імплантата. Хворі цієї категорії в анамнезі перенесли лапаротомію з приводу різної патології органів черевної порожнини (деструктивний панкреатит, перфоративна або кривавляча виразка, гостра кишкова непрохідність, секторальний тромбоз тощо).

89,9 \% хворих із пупковими грижами були госпіталізовані в стаціонар після амбулаторного обстеження. При защемлених грижах під час госпіталізації пацієнту проводили загальноклінічні, біохімічні, інструментальні (рентгенографія, УЗД, ЕКГ) дослідження. Після короткочасної корекції супутньої патології, оцінки ступеня операційного ризику і передопераційної підготовки всі хворі були прооперовані традиційним або ненатяжним методом.

37 пацієнтам з пупковими грижами, у яких діаметр пупкового кільця не перевищував 3 см, була виконана операція, розроблена в клініці. Суть ïï полягає в наступному: через пупок (рис. 1) проводили розріз шкіри та підшкірної клітковини до апоневрозу. Виділяли грижовий мішок, розсікали, вміст занурювали в черевну порожнину.

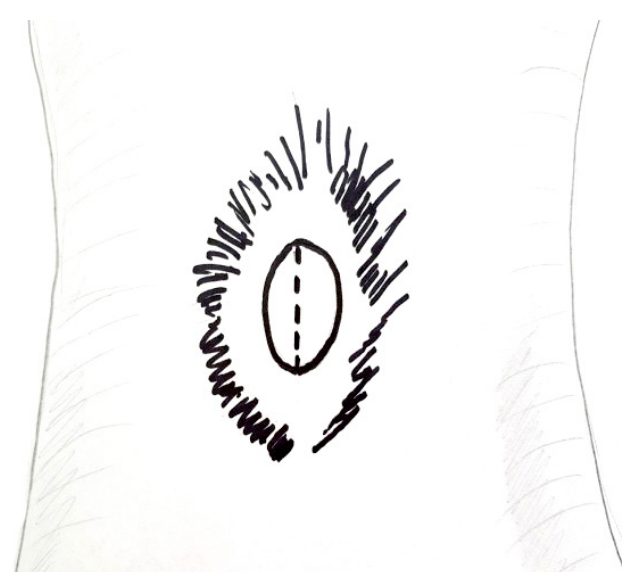

Рис. 1. Розріз шкіри.
Грижовий мішок перев’язували біля основи, відсікали або зашивали очеревину обвивним швом. Ретельно очищували розширене пупкове кільце від підлеглих тканин і проводили пластику за медом Мейо або іншим способом. Після цього висікали частину шкіри пупка, яка його деформувала, накладали оригінальний косметичний погружний шов (рис. 2), який захоплював дермальну частину шкіри й апоневроз. Вузол зав'язували під шкірою, яку зашивали косметичним швом за Пироговим (рис. 3, 4). Інколи ззовні накладали 1-2 вузлових шви на шкіру.

Після того, як розроблена в клініці методика була відпрацьована, почали аналогічним методом оперувати невеликі защемлені грижі (рис. 5, 6).

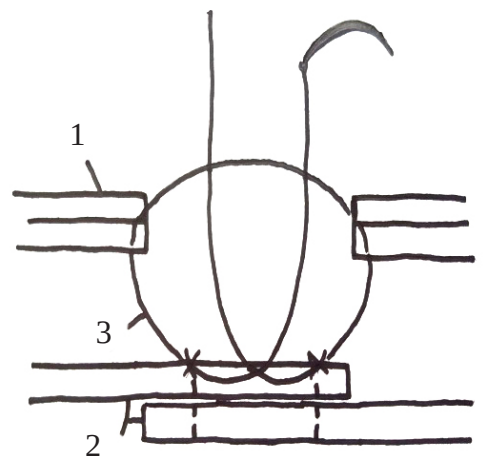

Рис. 2. Накладання косметичного погружного шва.

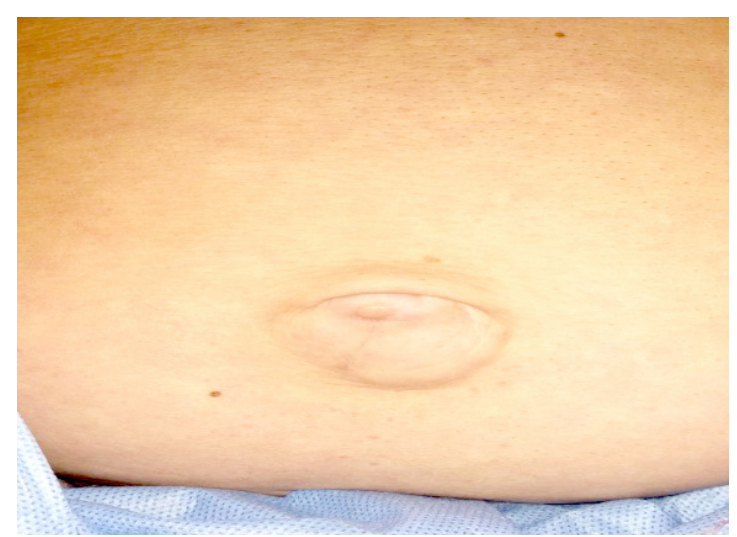

Рис. 3. Хворий Г., історія хвороби № 14973/19.

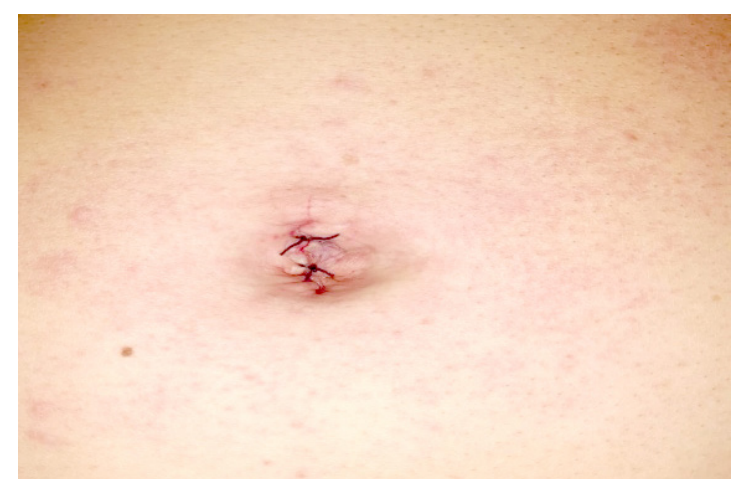

Рис. 4. Хворий Г. після операції. 


\section{З ДОСВІДУ РОБОТИ}

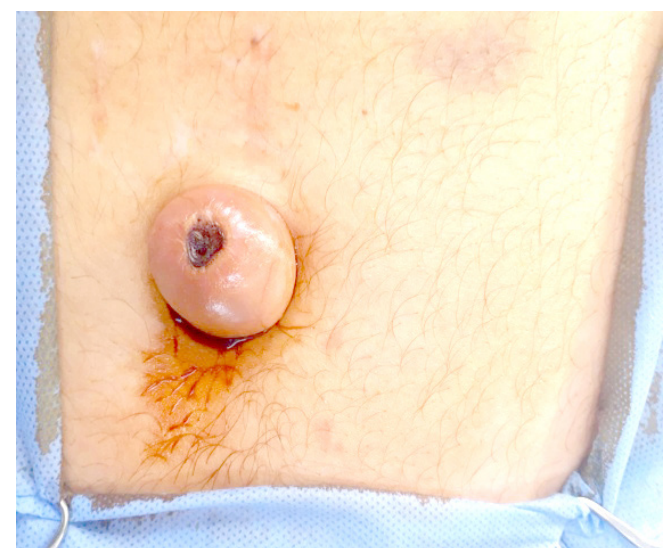

Рис. 5. Хворий Ж, історія хвороби № 11243/19

Результати досліджень та обговорення. Результати проведеного дослідження показали, що запропонований метод хірургічного лікування пупкових гриж малого діаметра істотно не впливає на тривалість операції і навіть потребує дещо менше часу. Сумарний показник тривалості операцій традиційним методом складав $(56,4 \pm 10,5)$ хв, а при виконанні операції за оригінальною методикою - $(51,4 \pm 7,7)$ хв. За частотою ранових ускладнень групи оперованих хворих не відрізнялися, це стосується й терміну їх перебування в стаціонарі - 3,1 ліжко/дня.

Косметичний ефект після пластики пупкової грижі із збереженням пупка має естетичне значення, особливо в молодих пацієнтів і жінок. Розро-

\section{СПИСОК ЛІТЕРАТУРИ}

1. Егнев В. Грыжи / В. Егнев, П. Воскресенський. - М. : Медпрактика, 2015. - 480 с.

2. Общая хирургия : учебник / Петров С. - 3-е. изд. перераб. и доп. - 2010. - 768 с.

\section{REFERENCES}

1. Egnev, V., \& Voskresenskiy, P. (2015). Gryzhi [Hernias]. Moscow: Medpraktika [in Russian].

2. Petrov, S. (2010). Obshchaya khirurgiya: uchebnik [General surgery; textbook] [in Russian].

3. Andrushchenko, V.P., \& Kushnirchuk, M.I. (2010). Osoblyvosti khirurhichnoho likuvannia pisliaoperatsiinykh ventralnykh

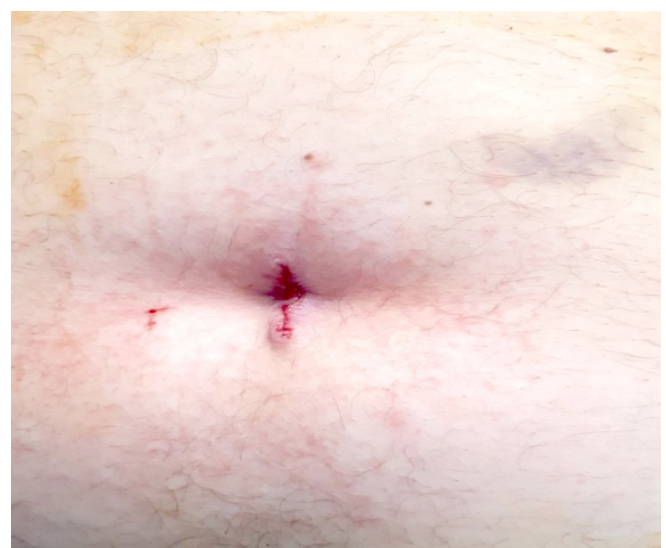

Рис. 6. Хворий Ж. після операції.

блена в клініці методика хірургічного лікування пупкових гриж невеликого діаметра дає змогу надійно ліквідувати дефект апоневрозу і домогтися естетичного ефекту після втручання.

Висновок. Запропонована методика хірургічного лікування пупкових гриж невеликих розмірів сприяє збереженню природних форм живота шляхом збереження пупка і ліквідації його деформованої частини.

Представлена методика герніопластики надійно ліквідує дефект пупкового кільця, забезпечує косметичний ефект, є надійною та простою, що зумовлює доцільність використання ії̈ при хірургічному лікуванні пупкових гриж малого діаметра.

3. Андрущенко В. П. Особливості хірургічного лікування післяопераційних вентральних та пупкових гриж живота зі збереженням косметичного ефекту втручання шляхом формування нового пупка / В. П. Андрущенко, М. І. Кушнірчук // Хірургія України. - 2010. - № 1 - С. 50-54.

ta pupkovykh hryzh zhyvota zi zberezhenniam kosmetychnoho efektu vtruchannia shliakhom formuvannia novoho pupka [Features of surgical treatment of postoperative ventral and umbilical hernia with preservation of cosmetic effect of the intervention by forming a new navel]. Khirurhiia Ukrainy - Surgery of Ukraine, 1, 50-54 [in Ukrainian]. 
Ivano-Frankivsk National Medical University ${ }^{1}$, Central City Clinical Hospital ${ }^{2}$

\section{SURGICAL TREATMENT OF UMBILICAL HERNIAS WITH PRESERVATION OF COSMETIC EFFECT}

The aim of the work: to develop a method for surgical treatment of umbilical hernias with preservation of the cosmetic effect. Materials and Methods. In the Surgical Department of the Central City Clinical Hospital of Ivano-Frankivsk for 2016-2018, 267 patients with umbilical hernias were operated on. 230 patients underwent traditional surgical interventions according to the Mayo technique, Sapezhko or with the use of allografts. 37 patients used the original method of surgery with preservation of the navel, which was developed in the clinic. Groups of patients by age, gender, type and duration of pathology were comparable.

Results and Discussion. The essence of the original methodology of the operation was as follows: an incision of the skin and subcutaneous fatty tissue before the aponeurosis is carried out through the navel vertically with respect to the human body in an upright position. A hernial sac was isolated, dissected, its contents were immersed in the abdominal cavity. The hernial sac was bandaged at the base and the peritoneum was cut off or sutured with a circumferential suture. Thoroughly cleansed the enlarged umbilical ring and part of the adjacent aponeurosis of adipose tissue and performed hernia repair using Mayo or other methods. After that, if necessary, part of the navel skin was carved if it deformed, and an original cosmetic immersion suture was applied, which captured the dermal part of the skin and aponeurosis. The knot was tied under the skin. The latter was sewn up with a cosmetic seam. Sometimes the skin suture was strengthened with 1-2 knotted sutures. The proposed method for surgical treatment of umbilical hernias of small diameter does not significantly affect the duration of the operation and even a few minutes shorter. So, the total indicator of the duration of the operation by the traditional method was (56.4 \pm 10.5$)$ minutes, and when performing the original method (51.4 \pm ) 7.7 minutes. The groups of operated patients did not differ in the number of wound complications. This also applies to the length of hospital stay - (3.1 \pm 1.1$)$ bed/day. The proposed method for surgical treatment of umbilical hernias of a small size $(2-3 \mathrm{~cm})$ helps to preserve the natural forms of the abdomen by restoring the navel and eliminating its deforming part.

Key words: umbilical hernia; incision through the navel; immersion cosmetic suture; cosmetic effect.

\section{М. Г. ГОНЧАР ${ }^{1}$, А. Е. БОГУШ², Л. Д. ПРИЙМАК}

Ивано-Франковский национальный медицинский университет ${ }^{1}$

Центральная городская клиническая больница ${ }^{2}$

\section{ХИРУРГИЧЕСКОЕ ЛЕЧЕНИЕ ПУПОЧНЫХ ГРЫЖ С СОХРАНЕНИЕМ КОСМЕТИЧЕСКОГО ЭФФЕКТА}

Цель работы: разработать методику операционного лечения пупочных грыж с сохранением косметического эффекта. Материалы и методы. В хирургическом отделении центральной городской клинической больницы Ивано-Франковска за 2016-2018 годы прооперировано 267 пациентов с пупочными грыжами. 230 больным выполнены традиционные оперативные вмешательства по методике Мейо, Сапежко или с применением аллотрансплантатов. 37 пациентам применена оригинальная методика операции с сохранением пупка, которая была разработана в клинике. Группы больных по возрасту, полу, видам и продолжительности патологии были сопоставимы.

Результаты исследований и их обсуждение. Суть оригинальной методики заключается в следующем: разрез кожи и подкожной клетчатки до апоневроза проводили через пупок вертикально по отношению к туловищу человека в вертикальном положении. Выделяли грыжевой мешок, рассекали, содержимое его погружали в брюшную полость. Грыжевой мешок перевязывали в основе и отсекали или зашивали брюшину обвивным швом. Тщательно очищали расширенное пупочное кольцо и подлежащий апоневроз от подлежащих тканей и проводили пластику по Мейо или другими способами. После этого, при необходимости, высекали часть кожи пупка, если она его деформировала, и накладывали оригинальный косметический погружной шов, который захватывал дермальный слой кожи и апоневроз. Узел завязывали под кожей, которую зашивали косметическим швом. Иногда шов укрепляли 1-2 узловыми швами. Предложенный метод хирургического лечения пупочных грыж существенно не влияет на продолжительность операции и даже занимает несколько меньше времени - суммарный показатель продолжительности операции традиционным методом составлял $(56,4 \pm 10,5)$ мин, а при выполнении операции по оригинальной методике - $(51,4 \pm 7,7)$ мин. По частоте раневых осложнений группы оперированных больных не отличались. Это касается и срока пребывания в стационаре - $(3,1 \pm 1,1)$ койко/дня.

Предложенная методика хирургического лечения пупочных грыж небольшого размера (2-3 см) способствует сохранению естественных форм живота путем восстановления пупка и ликвидации его деформирующей части.

Ключевые слова: пупочная грыжа; разрез через пупок; погружной косметический шов; косметический эффект. 